\title{
«MÁS»Y «MÁS» CON CRISTO. CRISTOLOGÍA Y SANTIDAD A LA LUZ DE «GAUDETE ET EXSULTATE» ${ }^{1}$
}

Fecha de recepción: 05 de febrero de 2020

Fecha de aceptación: 04 de marzo de 2020

RESUMEN: El Concilio Vaticano II presentó en el capítulo V de la constitución dogmática Lumen gentium la llamada universal a la santidad de todos los miembros del pueblo de Dios. El papa Francisco, en la exhortación apostólica Gaudete et exsultate, nos ha recordado la validez y la necesidad de acoger de nuevo esa llamada a ser santos en el contexto eclesial y cultural de nuestros días. El presente artículo reflexiona sobre los elementos más destacados del contenido de la exhortación con el objeto de esclarecer el hondo significado de esta llamada a la santidad; profundiza en la dimensión cristológica que expone el documento, así como en la relación que existe entre el misterio de Cristo y la vocación a la santidad. Siendo la llamada a la santidad un tema teológico de primer orden, esta debe inspirarse en quién es «el Santo de Dios» (Jn 6,69) para que en el encuentro personal con Cristo se vislumbre el modelo de santidad al que estamos llamados. El dinamismo de la santidad reclama la llamada y el encuentro con Cristo para configurar la existencia cristiana según la forma Christi. Sin Cristo no hay santidad, sin una Iglesia santa no habrá anuncio misionero ni evangelización.

PALABRAS CLAVE: Cristo; cristología; santidad; Iglesia; pastoral; misión.

"Centro Superior de Estudios Teológicos «San Pablo», Málaga: salvagilcanto@gmail.com

1 Este trabajo ha sido realizado con la ayuda del Centro Español de Estudios Eclesiásticos anejo a la Iglesia Nacional Española de Santiago y Monserrat en Roma en el marco de los proyectos de investigación del curso 2019-2020. 


\section{More and more with Christ. Christology and Holiness in the Light of "Gaudete et exsultate»}

ABSTRACT: The Second Vatican Council presented, in chapter V of the dogmatic constitution Lumen gentium, the universal call to holiness for all members of the people of God. Pope Francis, in his apostolic exhortation Gaudete et exsultate, has reminded of the validity and necessity of welcoming that call anew to become saints in the ecclesial and cultural context of our time. This paper reflects upon the most outstanding elements of the exhortation, aiming at a better understanding of the deep significance of this call to holiness. It looks into the Christological dimension suggested by the document, as well as the relationship between the mystery of Christ and the vocation to holiness. The call to holiness is a primary theological topic, based on He who is «the Holy One of God» (John 6,69). The model of holiness we are called to shines in the personal encounter with Christ. The dynamics of holiness demands the call by and the encounter with Christ, so that the christian existence is shaped after the forma Christi. Just as there is no holiness without Christ, there will be no missionary announcement or evangelization without a holy Church.

KEY WORDS: Christ; Christology; holiness; Church; pastoral; mission.

«Cada santo es una misión. Esa misión tiene su sentido pleno en Cristo y solo se entiende desde él».

Papa Francisco, GE 19-20

\section{LA EXHORTACIÓN APOSTÓLICA GAUDETE ET EXSULTATE}

¡Alegraos y regocijaos! El mes de marzo de 2018 el papa Francisco publicaba la exhortación apostólica Gaudete et exsultate sobre la llamada a la santidad en el mundo actual ${ }^{2}$. Se trata de un documento magisterial de talante espiritual y pastoral, con una teología que muestra el ideal de la vida cristiana.

Escrito con un lenguaje directo, claro y descriptivo, al estilo de Francisco, su humilde objetivo «es hacer resonar una vez más el llamado a la santidad, procurando encarnarlo en el contexto actual, con sus riesgos,

${ }^{2}$ Cf. Francisco. Exhortación apostólica Gaudete et exsultate. Sobre el llamado a la santidad en el mundo actual. (19 de marzo de 2018). Consultado el 14 de enero 2020. http:/vatican/va/content/francesco/es/apost_exhortations/document/papa_francesco_esortazione_ap_20180319_gaudete-et-exultate.html. (En adelante GE). 
desafíos y oportunidades. Porque a cada uno de nosotros el Señor nos eligió "para que fuésemos santos e irreprochables ante él por el amor" $(\mathrm{Ef} 1,4) »(\mathrm{GE} 2)^{3}$. De esta forma, la finalidad que persigue el documento «es que cada creyente discierna su propio camino y saque a la luz lo mejor de sí, aquello tan personal que Dios ha puesto en él (cf. 1Co 12,7)»(GE 11).

La exhortación consta de un preámbulo y cinco capítulos desarrollados en un total de 177 epígrafes. En el capítulo primero, cuyo título es el llamado a la santidad (nn. 3-35), propone la doctrina oficial de la Iglesia sobre la universal llamada a la santidad en continuidad con el Vaticano II, anima a todo el pueblo de Dios, y a cada uno de sus miembros en particular, a tomar conciencia de esta llamada para responder con generosidad. En el capítulo segundo, se presentan y analizan dos riesgos sutiles que son enemigos de la santidad: el gnosticismo y el pelagianismo (nn. 3664). Ambos son propuestas engañosas y dos formas de seguridad doctrinal o disciplinaria que dificultan la vivencia del cristianismo. A la luz del Maestro describe, en el capítulo tercero, las bienaventuranzas y el gran protocolo del juicio final (Mt 25,31-46) como enunciados de la santidad que estamos llamados a alcanzar (nn. 65-111). En nuestra opinión es el capítulo central, ya que la santidad reclama de la Iglesia imitar a Jesús como anticipo de lo que será la gloria final.

En el capítulo cuarto desarrolla algunas notas de la santidad en el mundo actual (nn. 112-158). Entre estas se destacan el aguante, la paciencia y la mansedumbre; la alegría y el sentido del humor, junto a la audacia y el fervor, vividas en comunidad y en constante oración. El último capítulo está dedicado al combate, la vigilancia y al discernimiento (nn. 159-177) como medios necesarios para avanzar en el camino de la santificación.

${ }^{3}$ En el n. 10 insiste: «lo que quisiera recordar con esta exhortación es sobre todo el llamado a la santidad que el Señor hace a cada uno de nosotros, ese llamado que te dirige también a ti: "sed santos, porque yo soy santo" (Lv 11,45; cf. 1P 1,16). El Concilio Vaticano II lo destacó con fuerza: "Todos los fieles, cristianos, de cualquier condición y estado, fortalecidos con tantos y tan poderosos medios de salvación son llamados por el Señor, cada uno por su camino, a la perfección de aquella santidad con la que es perfecto el mismo Padre”»(GE 10). Cita la Constitución sobre la Iglesia LG n. 11. Francisco explica que el documento no es un tratado sobre la santidad en el que con definiciones, distinciones y análisis se podría enriquecer este tema (cf. GE 2). 
GE nos vuelve a recordar el fin último al que cada cristiano está llamado: a ser santo. Y esto es posible para cada uno de nosotros, para todo el pueblo de Dios. Nadie puede quedar excluido de esta llamada ni mirar para otro lado: ¡No! Esta profunda y radical llamada — siguiendo a Francisco- es para todos ${ }^{4}$.

\subsection{El PUNTO DE PARTIDA: LG y LA VOCACióN UNIVERSAL A LA SANTIDAD}

El Vaticano II enseña en la Constitución Lumen gentium la vocación universal de todos los miembros del pueblo de Dios a la santidad. El capítulo V titulado "la vocación universal a la santidad en la Iglesia» ocupa los nn. 39-42. Además hay una referencia explícita al tema de la santidad en LG 11 que Francisco introduce en GE 10.

El jesuita G. Uríbarri ha subrayado que las dos columnas del Vaticano II para entender GE son Lumen gentium, donde se recoge la doctrina del pueblo santo de Dios, y Gaudium et spes, donde se presenta la misión de la Iglesia en el mundo. A esto hay que añadir la influencia del Documento de Aparecida ${ }^{5}$. Pero afinando un poco más conviene recordar que el papa Francisco alimenta su reflexión teológica y su ministerio pastoral en cuatro fuentes que sobresalen en él por su influjo y significado: la recepción del Vaticano II; la figura de Pablo VI y la Exhortación Evangelii nuntiandi; la teología argentina del pueblo y las Conferencias del Epis-

${ }^{4}$ Cf. Jaime López Peñalba. "La vocación universal a la santidad en Gaudete et exsultate”. Teología y catequesis 144 (2019): 31-56. Paul O’Callaghan. "Il significato ermeutico della chiamata universale alla santitá". PATH 18, n. ${ }^{\circ} 1$ (2019): 23-41. Dominique Rakotobe. "Los santos de la puerta de al lado". Revista de espiritualidad 308 (2018): 427-493. Antonio Spadaro. "Gaudete et exsultate. Radici, struttura e significato della Esortazione apostolica di papa Francesco”. La Civiltà Cattolica 4028, n. ${ }^{\circ} 2$ (2018): 107-123.

5 Cf. Gabino Uríbarri. Santidad misionera. Fuentes, marco y contenido de Gaudete et exsultate. Santander: Sal Terrae, 2019, 36-48; 98-105. Íd. "La santidad de los discípulos misioneros. La recepción del Concilio Vaticano II en Gaudete et exsultate". CONFER 58, n. ${ }^{\circ} 21$ (2019): 31-53. Cf. también Carlos María Galli. Dios vive en la ciudad. Hacia una nueva etapa pastoral urbana a la luz de Aparecida y del proyecto misionero de Francisco. 3. ${ }^{a}$ ed. Barcelona: Herder, 2014. Íd. "La teología pastoral de Aparecida, una de las raíces latinoamericanas de Evangelii gaudium”. Gregorianum 96 (2015): 25-50. 
copado Latinoameriano, en particular el Documento de Aparecida; y, la espiritualidad ignaciana propia de su ser jesuita ${ }^{6}$.

El Concilio presenta la doctrina sobre la universal vocación a la santidad de todos los miembros del pueblo de Dios sin excepción alguna. Dicha llamada es entendida en LG en los siguientes términos:

La Iglesia no puede dejar de ser santa porque «Cristo, el Hijo de Dios, a quien con el Padre y con el Espíritu se proclama "el solo Santo"7, amó a su Iglesia como a su esposa» (LG 39). En el n. 39 se dice de Cristo que «Él se entregó por ella para santificarla (cf. Ef 5,25-26), la unió a sí mismo como su propio cuerpo y la llenó del don del Espíritu Santo para gloria de Dios».

En LG 40 Jesús es presentado como modelo de toda perfección. Se afirma que el Señor Jesús, Maestro divino y modelo de toda perfección, predicó a todos y a cada uno de sus discípulos la santidad de vida, de la cual Él es el autor y consumador. Cristo envió a todos el Espíritu Santo para que los mueva interiormente y así amen a Dios con todo el corazón, con toda el alma, con todo el espíritu y con todas las fuerzas, y se amen unos a otros como Cristo nos amó. Los seguidores de Cristo, llamados por Dios, justificados en el Señor Jesús, mediante el bautismo y la fe participan de la naturaleza divina y son, por tanto, realmente santos. La llamada a la plenitud de la vida cristiana y a la perfección del amor es para todos los cristianos (omnes christifideles). Para alcanzar la perfección se ha de seguir las huellas de Cristo, conformándose a su imagen y siendo obedientes en todo a la voluntad del Padre.

LG 41 habla de la santidad en los diversos estados de vida dentro de la Iglesia. Cristo es denominado «sumo y eterno Sacerdote, Pastor y Obispo de nuestras almas»; y «eterno y único Mediador». Él debe ser imitado, puesto que «Cristo trabajó como obrero y trabaja siempre con el Padre para la salvación de todos» (cf. LG 41).

Por último, LG 42 al hablar de los consejos evangélicos enseña que «Jesús, el Hijo de Dios, mostró su amor dando su vida por nosotros. Por

${ }^{6}$ Cf. Uríbarri, 18-21. Cf. Ugo Sartorio. Santità per tutti. Una lettura dell'esortazione apostolica Gaudete et exsultate. Milano: Ancora, 2019, 8-14.

7 La expresión «el solo Santo» es justificada en el texto conciliar con las siguientes citas evangélicas: Lc 1,35; Mc 1,24; Lc 4,34; Jn 6,69 (el Santo de Dios); Hch 3,14; 4,27.30; Heb 7,26; 1Jn 2,20; Ap 3,7. Cf. Salvador Gil Canto. La Cristología del Vaticano II. Una relectura a los cincuenta años. Salamanca: Secretariado Trinitario, 2015, 79-81. 
eso, nadie tiene mayor amor que el que da su vida por Él y por sus hermanos» (LG 42; cf. 1Jn 3,16 y Jn 15,13). En relación al martirio se dice que el Maestro «aceptó libremente la muerte para la salvación del mundo» (LG 42). Y animando a los cristianos a amarse, se utilizan dos pasajes evangélicos que habían aparecido en LG 8: «Él se despojó de su rango y tomó la condición de esclavo y se hizo obediente hasta la muerte» (Flp 2,7-8), y, «por nosotros se hizo pobre, siendo rico» (2Cor 8,9) (LG 42).

\subsection{Dimensión CRISTOLÓGICA DE LA COMÚN LLAMADA A LA SANTIDAD}

Algunos autores han subrayado el aspecto cristológico del capítulo $\mathrm{V}$ de LG. Cristo, que ha predicado la perfección (cf. Mt 5,48), es al mismo tiempo el modelo y el maestro, el autor y el consumador, pues «solamente en Cristo, Hijo único y a imagen suya, podemos llegar a este tipo de perfección $»^{8}$.

La perfección cristiana a la que todos los miembros del pueblo de Dios están llamados reclama un esfuerzo orientado, en primer término, a Cristo, ya que se trata fundamentalmente de un don, de una perfección de amor, eliminando todos los obstáculos y tentaciones para la vida a la que Cristo nos llama. Ese don que Dios nos hace por su participación en la vida trinitaria es, en cierto modo, ontológico o sustancial ${ }^{9}$. No somos nosotros los que nos elevamos hacia él con nuestras fuerzas, como si de un esfuerzo de corte pelagiano se tratase, sino que es la santidad misma la que baja a nosotros. Sale a nuestro encuentro por la encarnación del Hijo de Dios y la misión del Espíritu Santo ${ }^{10}$.

8 M. Labourdette. "La santidad, vocación de todos los miembros de la Iglesia". En La Iglesia del Vaticano II. Vol. II, dirigido por Guillermo Baraúna, 1065-1066. Barcelona: Juan Flors, 1966. Cf. Ugo Rocco. "Universale vocazione alla santità nella Chiesa”. En La Costituzione dogmatica sulla Chiesa, 731-756. Torino: Elle Di Ci, 1965.

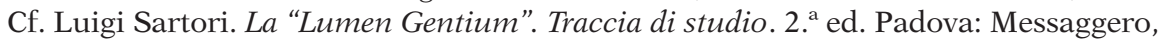
2003, 177-178. Sandra Mazzolini. "Vocazione universale alla santità nella Chiesa". En Commentario ai documenti del Vaticano II. Lumen gentium 2, dirigido por Serena Noceti y Roberto Repole, 355-375. Bologna: Dehoniane, 2015.

9 Cf. Labourdette, 1066-1067. Cf. Ignacio Iparraguirre. "Naturaleza de la santidad y medios para conseguirla”. En La Iglesia del Vaticano II. Vol. II, dirigido por Guillermo Baraúna, 1073-1088. Barcelona: Juan Flors, 1966.

10 Cf. Gérard Philips. La Iglesia y su misterio en el Concilio Vaticano II. Historia, texto y comentario de la Constitución «Lumen Gentium». Vol. II. Barcelona: Herder, 
Aunque la santidad tiene un sentido ontológico no se puede olvidar, sin embargo, su carácter dinámico en la línea que presenta el papa Francisco en GE. El perito conciliar G. Philips ha insistido en este aspecto al vincular este dinamismo con la encarnación del Hijo de Dios. De hecho, Dios a través de la encarnación de su Hijo y por medio del Espíritu Santo revela el carácter trinitario de la santidad, y el Espíritu de Cristo no cesa de comunicarla a la Iglesia. Jesús es santo desde el momento de su concepción; en su bautismo en el Jordán el Espíritu lo colma de dones y se transforma en el santo de Dios; el mismo Jesús amó a la Iglesia y se entregó por ella para santificarla ${ }^{11}$. Estos son solo algunos de los aspectos que Philips considera para ilustrar la relevancia del misterio de Cristo en orden a la santidad, tal y como aparecen en el Nuevo Testamento.

En consecuencia, puesto que Cristo se encarnó por todos, todos estamos llamados a la santidad. La encarnación le sirve de punto de partida para declarar el valor universal de la santidad: «Maestro y modelo de perfección, origen y consumación de toda santidad, Jesús propone su programa a cada uno de sus discípulos cualquiera que sea su estado civil o su condición ${ }^{12}$. Su programa es divino, ya que Él es el Hijo de Dios, pero a la vez se caracteriza por ser una llamada exterior y una estimulación interior hacia la perfección de la caridad por el Espíritu Santo que nos ha sido dado en el bautismo ${ }^{13}$.

Por último, Philips subraya el aspecto cristológico cuando habla de la caridad, de las múltiples formas de ejercicio de la única santidad, de los seglares y la santidad, de las vías y medios para alcanzarla y de los consejos evangélicos ${ }^{14}$. Todo esto nos lleva a concluir la importancia que tiene la dimensión cristológica en el capítulo V de LG, punto de partida para llegar a GE.

$1969,88$.

11 Cf. Philips, 92-94.

12 Philips, 97-98.

13 Cf. Philips, 98.

14 Cf. Philips, 100-101; 108-109; 127; 144; 148. "Por Cristo al Padre: tal es concretamente el camino de la caridad. La caridad es un don del Salvador. Para llegar a las cimas el justo se esfuerza en conformarse con la imagen de Cristo cumpliendo la voluntad del Padre», 106. Es evidente el valor del por. La caridad es cristocéntrica. En este sentido, el martirio es también «una asimilación perfecta a Cristo, que, en la cruz, nos rescató con su muerte libremente consentida», 138. 


\section{TEOLOGÍA Y SANTIDAD COMO BINOMIO INSEPARABLE}

En diversas ocasiones Francisco ha insistido en la relación que existe entre teología y pastoral (cf. EG 133; GE 45). La doctrina teológica que no se oriente a la finalidad evangelizadora de la Iglesia y su cuidado pastoral es tan inconcebible como aquella pastoral que no tenga en cuenta la Revelación y la Tradición de la Iglesia a la hora de la transmisión de la $\mathrm{fe}^{15}$. De este modo, doctrina (mensaje) y pastoral han de caminar unidas, se dan la mano. El encuentro entre ambas no es opcional, sino «constitutivo de una teología que pretenda ser eclesial ${ }^{16}$. La reflexión del mensaje cristiano (teo-logía) — superando la teología de «escritorio»— ha de abrir caminos para que este sea anunciado en la pastoral misionera en la que Francisco está insistiendo (cf. EG 133). Es más, la teología debe ayudar a que todo el pueblo de Dios viva la santidad como cualidad indispensable de la misión evangelizadora. La Iglesia que no es santa no será tampoco misionera ${ }^{17}$.

El papa Francisco secunda en GE una idea que ya había aparecido en el discurso de Juan XXIII en la apertura del Vaticano II, donde afirmó que «una cosa es la substancia de la antigua doctrina, del depositum fidei, y otra la manera de formular su expresión» ${ }^{18}$. La formulación será recogida en la Constitución pastoral GS 62 cuando enseña que «los teólogos están invitados a buscar siempre un modo más apropiado de comunicar las doctrinas a los hombres de su época, porque una cosa es el depósito mismo de la fe, o sea, sus verdades, y otra es el modo de formularlas conservando el mismo sentido y el mismo significado» (GS 62).

A nuestro modo de ver GE da un paso adelante y vincula la doctrina al principio de la encarnación, siendo que la doctrina no es un sistema cerrado, ni privado del dinamismo capaz de generar interrogantes, dudas y

15 Cf. Francisco. Discurso a la Comunidad académica del Pontificio Instituto "Juan Pablo II" (27 de octubre de 2016). AAS 108 (2016): 1230.

${ }^{16}$ Francisco. Videomensaje al Congreso Internacional de Teología organizado por la Pontificia Universidad Católica Argentina (1-3 de septiembre de 2015). AAS 107 (2015): 980. Cf. Francisco. Constitución apostólica Veritatis gaudium (8 de diciembre de 2017). AAS 110 (2018): 1-34.

17 Cf. Uríbarri, 38-42. Cf. Hans Urs von Balthasar. "Teología y santidad”. En Verbum Caro, 235-268. Madrid: Cristiandad, 1964.

18 Juan XXIII. Discurso en la solemne apertura del Concilio Vaticano II Gaudet Mater Ecclesia (11 de octubre de 1962). AAS 54 (1962): 792. 
cuestionamientos para dar una respuesta eficaz a la luz de las preguntas, angustias, deseos y luchas del pueblo santo puesto que estas poseen un valor hermenéutico que no se puede ignorar (cf. GE 44) ${ }^{19}$.

De esta forma la reflexión teológica, que pretende explorar los misterios divinos, debe tener su correlato en el ejercicio pastoral y evangelizador de la Iglesia para procurar una respuesta cada vez más profunda al amor de Dios, porque «se aprende para vivir: teología y santidad son un binomio inseparable» $(\mathrm{GE} 45)^{20}$. La teología debe llevar a vivir la santidad, esta última tiene su fundamento y punto de arranque en la teología, esto es, en el discurso sobre Dios y su revelación para que el mensaje cristiano pueda ser acogido por el hombre de hoy.

\section{DOS SUTILES ENEMIGOS DE LA SANTIDAD}

En el capítulo segundo de GE, el papa pone de relieve dos sutiles tentaciones que dificultan la vivencia de la santidad en nuestros días. En realidad son un nuevo modo de gnosticismo y de pelagianismo que se dan en el seno de la Iglesia. Las dos son propuestas engañosas que dificultan la vivencia del cristianismo, y que fueron superadas en los primeros siglos de la historia de la Iglesia. Las califica como «dos formas de seguridad doctrinal o disciplinaria que dan lugar a un elitismo narcisista y autoritario, donde en lugar de evangelizar lo que se hace es analizar y clasificar a los demás, y en lugar de facilitar el acceso a la gracia se gastan las energías en controlar» (GE 35; cf. EG 94).

Ambas expresan un inmanentismo antropocéntrico disfrazado de verdad católica y remiten, en definitiva, a una comprensión del hombre, de su ser y de su hacer cerrado a la gracia de Dios. «En los dos casos, ni Jesucristo ni los demás interesan verdaderamente» (GE 35) ${ }^{21}$.

${ }_{19}$ Cf. Francisco. Videomensaje al Congreso Internacional de Teología organizado por la Pontificia Universidad Católica Argentina (1-3 septiembre de 2015). AAS 107 (2015): 980.

20 El papa cita al final de GE 45 la Carta al Gran Canciller de la Pontificia Universidad Católica de Argentina en el centenario de la Facultad de Teología (3 de marzo de 2015). En L'Osservatore Romano, ed. semanal en lengua española (10 de marzo 2015): 6 .

21 De estos dos sutiles peligros había hablado en EG 94 al describir la mundanidad espiritual (cf. EG 93-97). Además, cf. Francisco. Discurso a los participantes en 


\subsection{El gNOSTICISMO COMO INMANENCIA DE LA RAZÓN}

El gnosticismo implica una fe encerrada en el subjetivismo donde la persona queda clausurada «en la inmanencia de la propia razón o de sus sentimientos» (GE 36; cf. EG 94). Se caracteriza por concebir una mente sin Dios y sin carne, por vivir una doctrina sin misterio y por sobrevalorar los propios límites de la razón humana (cf. GE 37-44). Situándose por encima del misterio, acentúa un Dios sin referencia a Cristo, un Cristo sin referencia a la Iglesia y una Iglesia sin referencia alguna al pueblo (cf. GE 37). O bien, reduce «la enseñanza de Jesús a una lógica fría y dura que busca dominarlo todo», sin referencia alguna a la carne (cf. GE 39).

En consecuencia, la santidad llega a ser una teoría con un lenguaje elitista y vacío. Significa que aunque la razón sea importante, esta tiene límites que pueden dificultar la apertura a lo espiritual, a lo sagrado, al misterio, a Dios. Y esto es evasión (cf. GE 40-46). Es por lo que el gnosticismo implica una rigidez y seguridad doctrinal que lleva al narcicismo y a la autorreferencialidad, tantas veces denunciada por el papa Francisco.

\subsection{El Pelagianismo como inmanencia de la Voluntad}

Lo que el gnosticismo es a la razón humana, el pelagianismo lo es a la voluntad. Ya sea en su forma habitual o en su derivado el semipelagianismo, se caracteriza por una voluntad sin humildad donde la gracia queda olvidada y se confía solo en las propias fuerzas personales (cf. GE 48-51).

En la vida de los cristianos se manifiesta de múltiples maneras. En el fondo es querer tener éxito rápido en nosotros mismos y en la vida pastoral: aquí, ahora, ya. Es vivir un cristianismo sin Cristo. Es confiar únicamente en las propias fuerzas humanas y cualidades sin contar con Dios. Es dejar de lado la primacía de la gracia, de modo que el hombre llegue a sentirse el centro del universo (cf. GE 46-57). Esta sutil pero real tendencia del pelagianismo lleva a una seguridad y rigidez disciplinar cuyas consecuencias, a veces, pueden conducir a un verdadero autoritarismo (cf. EG 94).

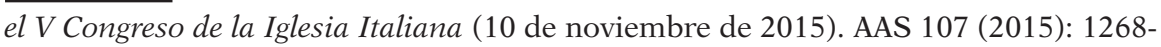
1271. Cf. Sartorio, 35-56. Uríbarri, 147-152; esp. 148. 


\subsection{VERDAD DE LA ENCARNACIÓN Y MUNDANIDAD ESPIRITUAL}

La verdad de la encarnación del Hijo de Dios, en opinión de Francisco, supera ambas tendencias descritas arriba. Así lo había ya enunciado el Vaticano II en la Constitución pastoral Gaudium et spes cuando, al referirse a este principio, afirma que «el Hijo de Dios con su encarnación se ha unido, en cierto modo, con todo hombre» (GS 22). Aquí se enseña que Jesús «trabajó con manos de hombre, pensó con inteligencia de hombre, obró con voluntad de hombre, amó con corazón de hombre» (GS 22). Habiendo nacido de la Virgen María, se hizo verdaderamente hombre, uno de los nuestros, semejante en todo a nosotros, menos en el pecado, y compartió realmente una vida familiar y social como Verbo encarnado (cf. GS 22, 32 y 38).

La encarnación del Hijo de Dios supera la mundanidad espiritual que se esconde detrás de una apariencia de falsa religiosidad y de amor cristiano en el que se buscan más los intereses personales y particulares de los creyentes que los de Cristo Jesús.

Esta mundanidad espiritual se manifiesta tanto en la actitud del gnóstico que considera la fe como un hecho puramente subjetivo y vivido encerrado en sí mismo, como en la actitud del pelagiano que, confiando solo en sus propias fuerzas, sintiéndose por encima de los demás, aparece como autorreferencial y prometeico (cf. EG 94). El papa insiste en que este es el peligro de una Iglesia que se manifiesta a veces como pura organización, privada "del sello de Cristo encarnado, crucificado y resucitado», que «no sale realmente a buscar a los perdidos ni a las inmensas multitudes sedientas de Cristo", que pierde el fervor evangélico y permanece en «el disfrute espurio de una autocomplacencia egocéntrica» (EG 95). En consecuencia, muchos cristianos consideran la justificación por sus propias fuerzas, la adoración de la propia voluntad y muestran aún más explícitamente una «autocomplacencia egocéntrica y elitista privada del verdadero amor» $(\mathrm{GE} 57)^{22}$.

${ }^{22}$ Cf. Francisco. Lumen fidei, n. 45. Francisco. Evangelii gaudium, nn. 93-94. Congregación para la Doctrina de la fe. Carta Placuit Deo a los Obispos de la Iglesia Católica sobre algunos aspectos de la salvación cristiana (22 de febrero de 2018), n. 3 . AAS 110 (2018): 428. Cf. Ángel Cordovilla. "La carta Placuit Deo sobre la salvación cristiana. Contenido y recepción”. Almeriensis 11 (2018): 333-342. Gabino Uríbarri. "Placuit Deo: tres claves de lectura. La carne de Cristo frente a dos dioses de nuestra cultura". Ecclesia 78, n. 3933 (2019): 24-25. Ambos en G. Uríbarri. o. c., 148 nota 36. 
Se hace necesario, pues, retomar el principio de la encarnación ${ }^{23}$ para superar la mundanidad espiritual. En efecto, con su encarnación «Jesús abre una brecha que permite distinguir dos rostros, el del Padre y el del hermano. No nos entrega dos fórmulas o dos preceptos más. Nos entrega dos rostros, o mejor, uno solo, el de Dios que se refleja en muchos» (GE 61).

\section{MEDIOS PARA ALCANZAR LA SANTIDAD}

El tercer capítulo de GE lo dedica el papa Francisco a profundizar en las bienaventuranzas y en Mt 25,31-46, como medios para poder alcanzar la santidad.

Las bienaventuranzas son como "el carnet de identidad del cristiano» (GE 63). Para llegar a ser un buen cristiano «es necesario hacer, cada uno a su modo, lo que dice Jesús en el sermón de las bienaventuranzas» (GE 63). El capítulo 25 del evangelio de Mateo establece lo que Francisco llama el gran protocolo sobre el cual seremos juzgados (cf. GE 95). Se trata de la expresión de la caridad manifestada en obras concretas de misericordia como camino para alcanzar la felicidad. El texto de Mateo — siguiendo a Juan Pablo II- no "es una simple invitación a la caridad sino una página de cristología, que ilumina el misterio de Cristo» (GE 96) ${ }^{24}$. Él ha querido identificarse en el rostro de los pobres y sufrientes para revelarnos sus opciones más radicales y sus sentimientos más profundos, en los que cada cristiano debe reconocerse.

En el texto de las bienaventuranzas y en Mt 25,31-46 hallamos lo que podríamos llamar una concentración cristológica santificante, es decir, la esencia de lo que la Iglesia está llamada a ser y vivir teniendo como centro existencial a Cristo para alcanzar la santidad. Cada miembro del pueblo de Dios debe vivir los dos pasajes evangélicos sine glosa, esto es, sin ningún tipo de comentarios, elucubraciones, rebajas o excusas que

Cf. Andrea Villafiorita. "Un nuovo ordine di relazioni in Cristo: note in margine alla Placuit Deo”. Rassegna di Teologia 59 (2018): 181-196.

${ }^{23}$ Cf. Karl Rahner. "Para la teología de la Encarnación”. En Escritos de Teología. Vol. IV. 131-148. 4. ${ }^{\text {a }}$ ed. Madrid: Cristiandad, 2002.

24 Cf. Juan Pablo II. Carta apostólica Novo millennio ineunte (6 enero 2001), n. 49. AAS 93 (2001): 302. Hay que observar las veces que el papa usa ambos textos. 
le resten fuerza a esta llamada de Cristo que nos invita a vivir desde «el corazón palpitante del Evangelio» (cf. GE 97; EG 271; MV 12).

El teólogo italiano L. Casula ha expuesto recientemente que el misterio de Cristo constituye el centro de la espiritualidad y de la perspectiva teológica del papa Francisco. Su cristología aparece profundamente enraizada en la Escritura, en continuidad con la Tradición de la Iglesia, pensada y vivida a la luz de la realidad y del contexto latinoamericano, sin ningún tipo de espiritualismos abstractos ni de reduccionismos ${ }^{25}$.

En GE aparece en bastantes ocasiones las referencias al elemento cristológico. La palabra Jesús se recoge en el documento cincuenta y siete veces, Cristo treinta y ocho veces, Jesucristo doce veces y el Señor un total de setenta y siete veces. Se evidencia que el misterio de Cristo tiene especial relevancia a la hora de abordar el tema de la santidad, impregnando toda la Exhortación bajo una perspectiva cristológica. Y aunque, en otro momento, hemos hablado de que uno de los rasgos de la cristología de Francisco es la cristología kerigmática ${ }^{26}$, podría afirmarse que aquí viene presentada como una cristología espiritual, propia de los grandes tratados de teología espiritual y de la espiritualidad cristiana. Espiritual en su sentido más genuino, propio del Espíritu de Dios. De hecho en GE la palabra Espíritu Santo aparece treinta y siete veces ${ }^{27}$. Se trata, por lo tanto, de un tipo de cristología pneumatológica, abierta a la presencia del Espíritu Santo, evitándose así cualquier tentación de presentar un tipo de cristología replegada en sí misma. Por ser una cristología de tipo espiritual puede desarrollar la dimensión propia de la pneumatología, de manera que la presencia del Espíritu hace posible que toda la Iglesia sea conducida a la fuente que es Cristo, para ser anunciado en el actual contexto cultural.

Bien podríamos decir que para Francisco espiritualidad puede ser sinónimo de santidad. En opinión de G. Uríbarri se podría afirmar que tanto en el Documento de Aparecida como en EG, al igual que en

${ }^{25}$ Cf. Lucio Casula. Volti, gesti e luoghi. La cristologia di papa Francesco. Città del Vaticano: Editrice Vaticana, 2017, 103. Para la cristología de Evangelii gaudium cf. Salvador Gil Canto. Cristo renueva a su Iglesia. Una reflexión a la luz del Vaticano II y la Evangelii gaudium. Málaga: Anarol, 2017, 69-92, esp. 79-92.

26 Cf. Gil Canto, 81-91.

27 Cf. GE 6, 9, 12, 15 (2 veces), 21 (2 veces), 23, 24, 27, 34, 42, 53, 57, 58 ( 2 veces), $65,73,122$ (2 veces), 124, 129, 132, 133 ( 2 veces), 139 ( 2 veces), 150, 164, 166 (2 veces), 167, 171, 172, 173, 175, 177. Cf. Uríbarri, 68 nota 26. 
GE, la espiritualidad que se propone se puede calificar como santidad misionera $^{28}$.

La teología espiritual tiene como objeto la vida del cristiano en cuanto vida espiritual en la que se encuentran unidos tanto el elemento ascético como el místico. Es el discurso sobre la vida espiritual como vida según el Espíritu, abierta a la perfección de la caridad en el encuentro y configuración del cristiano con Dios en Cristo, con la única intención de que todo el pueblo de Dios pueda responder al programa pastoral de Francisco de que la Iglesia se convierta en «un estado permanente de misión» (EG 25) ${ }^{29}$. Desde esta perspectiva pensamos que GE, si bien no es un tratado sobre la santidad, sí que contiene los elementos cristológicos necesarios para un verdadero progreso en la vida espiritual.

También en la exhortación postsinodal Christus Vivit, dedicada a los jóvenes, recordará de nuevo la centralidad de Cristo en la vida del creyente. En efecto, el cristianismo es «una Persona que me amó tanto que reclama mi amor. El cristianismo es Cristo» $(\mathrm{ChV} \mathrm{156})^{30}$.

${ }^{28}$ Cf. Uríbarri, 123-127. «La santidad misionera que habremos de encontrar en GE ha de ser muy aterrizada, para un contexto cultural, social e histórico determinado (cf. GE cap. II y IV); conjugando doctrina y pastoral; al servicio de los pobres (cf. GE 95-109), construyendo Iglesia que es Pueblo de Dios, pues se dirige a todos los bautizados (cf. GE cap. I)», 127. Y continúa señalando que «el reto principal de las Iglesias cristianas hoy en día se juega, al menos en los países occidentales, en la capacidad de convencer de la bondad de su oferta de espiritualidad. Es decir, en atraer y persuadir de que en el cristianismo se encuentra la verdadera alegría, la felicidad mayor que los humanos podemos experimentar en esta tierra», 127. Cf. Gabino Uríbarri. La mística de Jesús. Desafío y propuesta. Santander: Sal Terrae, 2017, 19-83. Íd. Teología de ojos abiertos: Doctrina, cultura y evangelización. Santander: Sal Terrae, 2018, 55-69. Cf. Santiago Madrigal. "La 'Iglesia en salida': la misión como tema eclesiológico". Revista Catalana de Teología 40, n. ${ }^{\circ} 2$ (2015): 425-458.

29 Cf. Augusto Guerra. "Teología espiritual”. En Nuevo Diccionario de Espiritualidad, dirigido por Stefano de Fiores, Tullo Goffi, y Augusto Guerra, 1841-1845. 5. ${ }^{\circ}$ ed. Madrid: Paulinas, 1991. Cf. Rafael Checa. "Pastoral de espiritualidad". En ibid., 1484-1500.

30 Cf. Francisco. Exhortación apostólica Christus Vivit (25 de marzo 2019), nn. 156 y ss. http://www.vatican.va/content/francesco/es/apost_exhortations/documents/papa_ francesco_esortazione-ap_20190325_christus-vivit.html. Consultado el 26 de enero de 2020 . 


\subsection{Misericordia De Dios y SANTIDAD}

Otro aspecto que se subraya en GE es la estrecha vinculación entre misericordia de Dios y santidad. La misericordia es para Francisco la propiedad fundamental del ser de Dios y la más grande de las virtudes (cf. GE 105-106). Esta no puede ser considerada solamente como un valor moral o espiritual, sino como un principio hermenéutico necesario para reavivar una renovación profunda de la Iglesia. Es un instrumento ineludible para avanzar en el camino de la santidad. En cuanto principio hermenéutico, la misericordia conlleva un cambio radical de método, al hacer posible el paso de un método deductivo a un método inductivo. De este modo, el punto de partida para la teología y para la vida cristiana no deben ser los principios doctrinales o los criterios teológicos usados en función de la interpretación de la realidad, sino la realidad en sí misma ${ }^{31}$. Y esta realidad a la que nos referimos tiene su centro de atención en el hombre a quien Dios le ofrece su amor misericordioso. No se trata de contraponer la vía antropológica a la teológica, sino de asumir la centralidad del hombre en cuanto persona, que es determinada e iluminada por la Palabra de Dios, y que proviene de las exigencias teológicas y cristológicas.

En este orden de cosas conviene remarcar que el magisterio de Francisco está conjugando simultáneamente tres conceptos que aparecen en intrínseca relación: misericordia de Dios, donde el rostro de Cristo adquiere su primacía en los pobres. El papa no ha dejado de insistir en la misericordia como eje vertebrador de todo su pontificado ${ }^{32}$. Por esta razón anima al pueblo de Dios a que la tarea evangelizadora se fundamente en la misericordia. En EG, citando a santo Tomás ${ }^{33}$, llega a escribir que la

31 Cf. Casula, 103-104. Cf. Gil Canto, 88-91.

32 Basta recordar el Año jubilar extraordinario de la Misericordia con la Bula de convocatoria Misericordiae vultus (11 abril 2015) y la Carta apostólica de clausura Misericordia et misera (20 noviembre 2016). Cf. Philipp Müller. "Miserando atque eligendo". En El evangelio de la misericordia, dirigido por George Augustin, 85-98. Santander: Sal Terrae, 2016. Y el también citado por Francisco al comienzo de su pontificado, Walter Kasper. La misericordia. Clave del Evangelio y de la vida cristiana. 7. ${ }^{\text {a }}$ ed. Santander: Sal Terrae, 2015. Cf. Pontificio Consejo para la Promoción de la Nueva Evangelización. Misericordiosos como el Padre. Subsidio para el Jubileo de la Misericordia 2015-2016. Madrid: BAC, 2015.

33 Cf. Santo Tomás. Summa Theologiae II-II, q. 30, art. 4. 
misericordia «es la más grande de las virtudes, ya que a ella pertenece volcarse en otros y, más aún, socorrer sus deficiencias» (EG 37). La vivencia de esta virtud se expresa en el obrar exterior y hunde su raíz en «la fe que se hace activa por la caridad» $(\mathrm{Ga} 5,6)$.

\subsection{Vía Jesús: KéNOSIS y hUMiLdad}

La santidad que Dios regala a su Iglesia viene a través de la humillación de su Hijo: ese es el camino. Esta perspectiva nos introduce en el tema de la kénosis de Jesús, quien «siendo de categoría divina se despojó de su rango y se humilló hasta la muerte en la cruz» (Flp 2,6-11). Dos momentos de un mismo acto se pueden diferenciar en este movimiento de abajamiento en la vida de Jesús. El primero es la encarnación del Hijo de Dios al asumir la naturaleza humana (cf. Jn 1,14). El segundo la muerte en la cruz como la expresión de un total anonadamiento y abajamiento. Con la encarnación, Dios ha compartido la condición humana hasta hacerse una sola cosa con los hombres en la persona de Jesús. Él se ha hecho hombre realmente, asumiendo la misión que el Padre le ha confiado, llevándola a cumplimiento con humildad hasta la entrega total de la vida.

El Vaticano II ha enseñado en LG 8 que la Iglesia está llamada a seguir la vía Jesús. Por vía Jesús entendemos el modo y la forma que Jesús tomó para salvar y redimir a los hombres: la entrega humilde de su existencia. Esta vía consiste en imitar a Cristo que tomó la condición de siervo y se hizo pobre a pesar de ser rico (cf. 2Cor 8,9). La tarea que el Concilio encomienda a la Iglesia es predicar también con su ejemplo, la humildad y la renuncia sin buscar la gloria de este mundo.

Además, el fundamento de la predicación de la Iglesia lo afirma LG 8 en el envío de Cristo a anunciar «la Buena Nueva a los pobres, a sanar, a buscar y a salvar lo que estaba perdido» (cf. LG 8, AG 3 y 5). Por ello la entera comunidad cristiana está llamada a descubrir en los pobres y en los que sufren la imaginem fundatoris - a su fundador-que es Cristo. Asimismo, cada bautizado debe imitar y vivir la imagen de Cristo pobre y sufriente, ha de preocuparse de aliviar su miseria y ha de buscar servirlo entre los más pobres y desfavorecidos ${ }^{34}$.

\footnotetext{
${ }^{34}$ Algunos autores que han desarrollado esta cuestión. Cf. Yves Marie Congar. Pour une Église servante et pauvre. Paris: Du Cerf, 1963. Marie Dominique Chenu. 
En este camino de santidad, la vía de la humillación lleva a asemejarnos a Jesús. Es parte ineludible de la imitatio Christi, como bien recuerda el apóstol Pedro: «Cristo padeció por vosotros, dejándoos un ejemplo para que sigáis sus huellas» (1Pe 2,21). Puede que resulte poco atractivo pero llega a ser un camino para configurar la existencia con Jesús y crecer en unión con él (cf. GE 118-120). Es un camino para avanzar por la senda de la santidad. Para ello es necesario un corazón que sea pacificado por el mismo Cristo, un corazón convertido y purificado del egoísmo. GE insiste en que el único que puede darnos ese don es Cristo, «nuestra paz» (Ef 2,14), que vino "para guiar nuestros pasos por el camino de la paz» (Lc 1,79) (cf. GE 121). De tal modo que Cristo es el don por medio del cual podemos alcanzar la santidad.

\subsection{Alegría y SANTidAD}

El magisterio de Francisco se ha caracterizado desde sus inicios por el tema de la alegría, que no ha dejado de ser una propuesta recurrente desde su primera Exhortación programática Evangelii gaudium ${ }^{35}$. También en

Église et pauvreté. Paris: Du Cerf, 1965; Íd. “'La Iglesia de los pobres' en el Vaticano II". Concilium 13, n. ${ }^{\circ} 2$ (1972): 73-79. Posteriores al Concilio, cf. Leonardo Boff. Jesucristo y la liberación del hombre. Madrid: Cristiandad, 1981. Eloy Bueno. Los rostros de Cristo en la teología contemporánea. Madrid: BAC, 1997. José Ignacio González

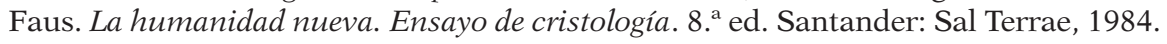
Gustavo Gutiérrez. En busca de los pobres de Jesucristo. Salamanca: Sígueme, 1993. Julio Lois. Jesús de Nazaret, el Cristo libertador. Madrid: Hoac, 1995. Jon Sobrino. Jesucristo liberador. Madrid: Trotta, 1991. Íd. La fe en Jesucristo. Ensayo desde las víctimas. Madrid: Trotta, 1999. Joan Planellas i Barnosell. La Iglesia de los pobres en el Concilio Vaticano II. Barcelona: Herder, 2014. Para esta cuestión en EG puede cf. Corintios XIII. Evangelii gaudium. Los pobres en el corazón de la misión de la Iglesia, 149 (2014).

35 Cf. Francisco. Evangelii gaudium, nn. 2-13. Amoris laetitia, nn. 1-7. Gaudete et exsultate, nn. 122-128. Cf. Carlos María Galli. "La gioia e la tenerezza del Vangelo. Il 'Codice Francesco'”. Vita Pastorale 3 (2014): 62-65. Íd. "La teología pastoral de Evangelii gaudium en el proyecto misionero de Francisco”. Revista Teología 114 (2014): 2959. Cf. Jorge Benedetti, y Carlos María Galli. Francisco: la alegría que brota del pueblo. Una reflexión compartida de Evangelii gaudium. Buenos Aires: Santa María, 2015. Cf. Antonio Spadaro. "Radici, struttura e significato della prima Esortazione apostolica di papa Francesco”. La Civiltá Cattolica 3923 (2013): 417-433. 
GE el papa ha querido subrayar la centralidad de la alegría al vincularla con el tema de la santidad.

Se trata de una alegría sobrenatural que vive y transmite todo aquel que se ha dejado contagiar de algún modo por la santidad. En efecto, «el santo es capaz de vivir con alegría y sentido del humor. Sin perder el realismo, ilumina a los demás con un espíritu positivo y esperanzador» (GE 122).

La vida cristiana consiste en vivir el gozo del Espíritu Santo que se nos dona gratuitamente. El Espíritu nos conduce siempre al gozo y a la alegría que se expresa en una vida transida de caridad. De esta forma, caridad y alegría se dan la mano, caminan como cualidades esenciales que caracterizan la vida de los santos.

Fundada en la Palabra de Dios, en especial en los profetas y en la vida de la Virgen María, Francisco describe las particularidades de esta alegría, fruto de la santidad y herramienta que conduce a ella (cf. GE 123-124).

También en los momentos difíciles y de sufrimiento dicha alegría no pierde su estado sobrenatural ya que «se adapta y transforma, y siempre permanece al menos como un destello de luz que surge de la certeza personal de ser amado infinitamente, más allá de todo» (GE 125). Para Francisco, esta alegría vinculada a los santos es «una seguridad interior, una serenidad llena de esperanza que ofrece una satisfacción espiritual incomprensible según los criterios mundanos» (GE 125; cf. EG 2-8).

Ahora bien, la alegría que él describe no es la alegría consumista o individualista tan presente en la cultura de nuestros días. El consumismo solo puede ofrecer placeres puntuales y temporales, pero no ofrece esta alegría llamada sobrenatural. Pues se refiere «a esa alegría que se vive en comunión, que se comparte y se reparte, porque "hay más alegría en dar que en recibir" (Hch 20,35)» (GE 128). Esta es la paradoja de la vida cristiana: que el amor verdadero multiplica nuestra capacidad de alegrarnos, ya que nos permite regocijarnos en el bien de los otros; y, en cambio, cuando nos centramos en nosotros mismos y en nuestras propias necesidades entonces languidecemos, y nos «condenamos a vivir con poca alegría» (GE 128). Es en esta situación cuando al creyente le asalta la tristeza y el pesimismo. 


\section{VIVIR LOS MISTERIOS DE CRISTO}

El proceso que cada cristiano está llamado a recorrer para desarrollar su misión en nuestros días es un camino que tiene su origen en la voluntad de Dios (cf. 1Tes 4,3). Es necesario recordar que cada santo es una misión (cf. GE 19). Pero esa misión adquiere «su sentido pleno en Cristo y solo se entiende desde él» porque en realidad la santidad «es vivir con él los misterios de su vida» (GE 20).

Los números 20 al 24 de GE desarrollan una perspectiva cristológica que nos sitúan ante el misterio de Cristo. Vivir en unión con Cristo y con los misterios de su vida radica en: asociarse a su muerte y resurrección de manera única y personal, muriendo y resucitando constantemente con él; y reproducir en la existencia distintos aspectos de la vida terrena de Jesús tales como su vida oculta, su vida comunitaria, su cercanía a los últimos, su pobreza u otras manifestaciones de su entrega por amor (cf. GE 20).

En estos últimos tiempos se ha recuperado de nuevo la reflexión y la contemplación de los misterios de la vida de Cristo. Algo que nunca fue olvidado por la cristología pero que en nuestros días ha adquirido una cierta relevancia gracias a la aparición de diversas publicaciones y propuestas cristológicas en esta perspectiva. Siguiendo el Concilio Vaticano II, que enseña que el Hijo de Dios asumió de María la naturaleza humana para liberar al hombre del pecado "por los misterios de su carne» (LG 55), hay quien ha subrayado que los misterios de Jesús son el despliegue de la encarnación a lo largo de su vida hasta su final en la Pascua ${ }^{36}$.

Para Francisco el fin de la vivencia de estos misterios cristológicos no es otro que «hacerlos carne en nuestras opciones y actitudes», como propone san Ignacio de Loyola en los Ejercicios espirituales ${ }^{37}$. Las razones

36 Cf. Karl Rahner. "Problemas actuales de cristología”. En Escritos de Teología. Vol. I. 167-221. Madrid: Taurus, 1961. Íd. "Eterna significación de la humanidad de Jesús para nuestra relación con Dios”. En Escritos de Teología. Vol. III. 47-59. Madrid: Taurus, 1962. Más recientemente, cf. Gabino Uríbarri. La singular humanidad de Jesucristo. Madrid: San Pablo, 2008. José Granados. Teología de los misterios de la vida de Jesús. Salamanca: Sígueme, 2009. Francisco A. Castro Pérez. Luz de los hombres. Fundamentos de antropología pastoral. Santander: Sal Terrae, 2019, 53-66.

37 Cf. Ignacio de Loyola. Ejercicios espirituales. Santander: Sal Terrae, 2010, 43-111. 
que justifican la contemplación y vivencia de estos misterios son expuestos por el papa al hilo de lo que enseña el catecismo de la Iglesia: «Todo en la vida de Jesús es signo de su misterio, toda la vida de Cristo es Revelación del Padre, toda la vida de Cristo es misterio de Redención, toda la vida de Cristo es misterio de Recapitulación, y todo lo que Cristo vivió hace que podamos vivirlo en él y que él lo viva en nosotros» (GE 20) ${ }^{38}$.

\subsection{FiJar la mirada en CRisto}

Para poder imitar a Cristo es necesario fijar la mirada en él. La primera tarea del creyente es fundar su vida en Cristo. Francisco lo propone como un elemento ineludible para responder con audacia y parresía a la misión. «Miremos a Jesús: su compasión entrañable no era ensimismada, ni paralizante, tímida o avergonzada». La compasión de Jesús lleva «a salir de sí con fuerza para anunciar, para enviar en misión, para enviar a sanar y a liberar» (GE 131).

El elemento contemplativo adquiere significación crística cuando el cristiano es capaz de centrar(-se) su existencia en el misterio de Cristo. GE insiste en ello cuando afirma que la contemplación del rostro de Jesús muerto y resucitado es la que recompone nuestra humanidad, también la que está rota por las fatigas de la vida o señalada por el pecado: «No hay que domesticar el poder del rostro de Cristo» (GE 151) ${ }^{39}$.

En este sentido, podemos afirmar que aquí se dibuja una cristología performativa que se halla con anterioridad en la Constitución GS del Vaticano II. Su finalidad es mostrar a Cristo que quiere entrar en relación personal con el hombre desde una implicación existencial, a través de la comunidad de la Iglesia; que se hace presente en la vida de los hombres, del entero pueblo de Dios y del mundo. Se trata de una cristología que no solo hace referencia al misterio de Cristo desde el punto de vista del contenido, sino a sus implicaciones en la existencia concreta de cada creyente llamado a la santidad. Su objetivo consiste en provocar en el hombre un encuentro existencial con Cristo muerto y resucitado para que se deje transformar por Él; y una vez transformado

\footnotetext{
38 Cf. Catecismo de la Iglesia Católica, nn. 515-518; n. 521.

39 Cf. Francisco. Discurso a los participantes en el V Congreso de la Iglesia Italiana (10 de noviembre de 2015). AAS 107 (2015): 1268-1271.
} 
pueda seguirle cada vez más radicalmente ${ }^{40}$. Sin este encuentro con Cristo no habrá santidad.

Es coherente que el papa insista en que Cristo va siempre más allá de nuestros esquemas y utilice la imagen de la periferia para referirse a su misterio: «Él mismo se hizo periferia» (GE 135). Por eso, si nos atrevemos a llegar a las periferias, allí lo encontraremos. Él estará allí. Nos primerea en el corazón de aquel hermano, en su carne herida, en su vida oprimida, en su alma oscurecida. Él ya está allí (cf. GE 135).

Francisco ofrece uno de los pasajes más bellos cuando escribe: «Es verdad que hay que abrir la puerta del corazón a Jesucristo, porque él golpea y llama (cf. Ap 3,20)». E insiste al preguntarse «si, por el aire irrespirable de nuestra autorreferencialidad, Jesús no estará ya dentro de nosotros golpeando para que lo dejemos salir» (GE 136). El verdadero encuentro con Jesucristo tiene esta doble dinámica: Jesús nos invita a salir y debemos dejar salir a Jesús.

El encuentro con Jesús en las Escrituras (cf. GE 156) nos lleva a la eucaristía, donde esta misma Palabra alcanza su máxima eficacia porque es presencia real del que es la Palabra viva. Allí, el único Absoluto recibe la mayor adoración que se le puede dar porque es el mismo Cristo quien se ofrece por nosotros (cf. GE 157).

\subsection{Para Superar todo combate}

Jesús mismo se alegra de nuestras victorias frente al combate contra el mundo y la mentalidad alejada de Dios para alcanzar la santidad (cf. GE 159). En la oración del padrenuestro quiso que terminásemos pidiendo a Dios Padre que nos libre del mal. Este mal no es un algo abstracto y debe ser traducido por el Malo ya que indica un ser personal que nos hostiga. Jesús nos instruye a pedir constantemente esa liberación

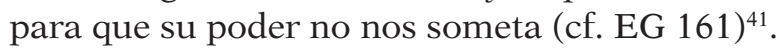

${ }^{40}$ Cf. Salvador Gil Canto. Cristo en el Vaticano II. Una relectura a los cincuenta años. Salamanca: Secretariado Trinitario, 2015, 271-273. Cf. María del Carmen Aparicio Valls. "La Palabra significativa". En Del clavo a la clave. La teología fundamental del papa Francisco, dirigido por Michelina Tenace, 19-28, esp. 22-25. Madrid: BAC, 2018. Cf. Francisco. Evangelii gaudium, n. 266.

${ }^{41}$ Cf. Sartorio, 101-104. 
Para superar todo tipo de combate, superando así el fracaso y la mediocridad, el mismo Señor nos ofrece las armas poderosas de la fe que se expresa en la oración, la acogida y meditación de la Palabra de Dios, la celebración de la eucaristía, la adoración eucarística, la reconciliación sacramental, las obras de caridad, la vida comunitaria y el empeño misionero (cf. EG 163). Antes y previo a ello, está siempre su gracia. No hemos de contentarnos con una vida superficial, a medias tintas. Es necesario emprender un camino de maduración espiritual y crecimiento en el amor para poder resistir al mal. El triunfo en la vida cristiana es siempre una cruz, "pero una cruz que al mismo tiempo es bandera de victoria, que se lleva con una ternura combativa ante los embates del mal» (GE 163; cf. EG 85). Conviene recordar que Cristo a través de su muerte y resurrección ha vencido el pecado y la muerte, ha vencido el mal. Participar del misterio pascual de Cristo implica participar de esa victoria sobre el mal.

\section{LA CRISTOLOGÍA DE GAUDETE ET EXSULTATE}

No hay santidad posible si no es desde el encuentro vital y existencial con Cristo, al igual que no hay evangelización si no hay discípulos misioneros que vivan cada día con mayor intensidad la llamada a la santidad. A la luz de GE 20 es necesario introducir la reflexión de la vida de Cristo y de sus misterios para crecer en el camino de la santidad. El papa Francisco ofrece en este número una hermosa página que permite desarrollar los siguientes rasgos cristológicos.

\subsection{JESÚS ES SIGNO DE SU MISTERIO}

Toda la vida de Jesús es signo, expresión y reflejo del misterio de Dios. El Hijo de Dios hecho hombre es el sacramentum — signo- visible del Dios invisible. Signo eficaz de la gracia de Dios entre nosotros, es el Enmanuel. El primer rasgo que caracteriza la cristología de GE es la presentación de Jesús como signo o sacramento de Dios. Esta línea de pensamiento se desarrolla en Pablo, donde encontramos la identificación entre la persona de Jesús y el misterio de Dios. Cristo es el auténtico mysterion de Dios pues recapitula el eterno designio de Dios, su realización 
y su revelación (cf. Rom 16,25; Col 2,2). Ignacio de Antioquía, Justino o Melitón de Sardes, entre otros, enriquecieron el concepto aplicándolo a los misterios de la vida de Cristo.

A lo largo del siglo II, mysterion adquirió tres significados. Por un lado, significó «el eterno designio de Dios», el cual se ha realizado y revelado como una poderosa acción salvífica en la persona y en la vida de Jesús; por otro, se aplicó a «la misma persona de Cristo» que, en cuanto acontecimiento de salvación, incorpora una revelación y una realización en el mundo y en el tiempo de la eterna gracia divina. Por último, se refirió a «las prefiguraciones y las profecías en las que el misterio de Jesús se revela de un modo transitorio y oscuro ${ }^{42}$.

A partir del siglo III, Orígenes introdujo en este concepto una idea que se impuso en el pensamiento cristiano: la vida de Jesús, su muerte y resurrección constituyen ciertamente la realización definitiva de la salvación, aunque pendiente de extenderse a toda la humanidad. En este sentido, el misterio que ya se ha realizado y revelado en el cristianismo está aún en tensión hacia el futuro, hacia su plena consumación. El vocablo en este tiempo comienza a designar también los grandes ritos de la eucaristía y del bautismo. Esta concepción se impondrá con rapidez en el ámbito latino más que en el griego.

Durante los siglos IV y V, el término latino sacramentum y el griego mysterion se convirtieron prácticamente en sinónimos, designando tanto el plan divino de salvación como las figuras del A. T. y los misterios cristianos. A principios de la Edad Media, sacramentum será el nombre clásico utilizado para designar los siete signos sacramentales y mysterion se usó para denominar los misterios doctrinales.

En definitiva, la enseñanza de la antigua Iglesia sobre el mysterion-sacramentum designa principalmente una estructura general comprensible en el todo de la economía salvífica y en sus diversas partes. La categoría sacramental indicaba, pues, la encarnación del plan salvador de Dios que a través del sacramentum se hace presente entre y para los hombres en la persona de Jesús el Hijo de Dios. Esta misma tradición cristológica, de hondo calado en la historia de la teología, es la que Francisco nos presenta cuando afirma «todo en la vida de Jesús es signo de su misterio» (GE 20).

${ }^{42}$ Gil Canto, 33-34. Cf. René Latourelle. Cristo y la Iglesia signos de salvación. Salamanca: Sígueme, 1971. Íd. Teología de la revelación. 11. a ed. Salamanca: Sígueme, 2005. 


\subsection{Cristo es el Revelador y La Revelación del Padre}

El segundo aspecto a destacar en la perspectiva cristológica de GE es la consideración de que Cristo es el revelador por excelencia de Dios. Él es quien nos ha revelado al Padre y nos lo ha dado a conocer (cf. Jn 1,18 ) porque nos ha comunicado lo que ha oído del Padre (cf. Jn 3,3.32; $8,26 ; 15,15)$.

Para el papa Francisco, Jesucristo no es solo el revelador del misterio de Dios sino que además es la suma revelación del Padre, haciendo referencia a $\mathrm{Hb} 1,1-3^{43}$. El autor de la carta a los Hebreos presenta a Cristo no solo como el sujeto mediador de la revelación sino también como el objeto de la manifestación de Dios. El papa explica: «Dios nos manifiesta a Cristo. Dios nos salva según su proyecto y su gracia. Esta nos ha sido dada en Jesucristo desde la eternidad, pero ha sido revelada ahora con la manifestación de nuestro salvador Cristo Jesús» ${ }^{44}$. Se concreta así la afirmación de DV 2 al presentar a Cristo como «mediador, culmen y plenitud de la revelación divina» (DV 2).

Jesús no es solo el revelador del Padre sino es también aquel que el Padre revela a los hombres. Él es al mismo tiempo el revelador y la revelación ${ }^{45}$. Toda la vida de Cristo es manifestación y revelación del Padre porque es el don más grande que el Padre nos ha dado para manifestarnos su amor. Siguiendo la afirmación joánica «en esto se manifestó el amor que Dios nos tiene: en que Dios envió al mundo a su Unigénito, para que vivamos por medio de él» (1Jn 4,9), se puede señalar que Jesús

${ }^{43}$ Cf. Jorge Mario Bergoglio - Papa Francesco. Aprite la mente al vostro cuore. Milano: Rizzoli, 2014, 125. Cf. Juan Alfaro. Revelación cristiana, fe y teología. Salamanca: Sígueme, 1974, 65-88.

${ }_{44}$ Jorge Mario Bergoglio - Papa Francesco, 126. La traducción del italiano es nuestra.

45 Ampliando esta cuestión K. Barth había afirmado que Dios mismo es el revelador, la revelación y lo revelado. Cf. Karl Barth. Dogmatique. La doctrine de la parole de Dieu. Vol. I. Genéve: Labor et Fide, 1953, 51. «La Parole de Dieu, c’est Dieu lui-meme dans sa révélation. Car Dieu se révèle come le Seigneur. En ce qui concerne le concept de révélation de l'Ecriture, cela signifie que Dieu lui-meme, dans son inalterable unitè, mais aussi dans son inaltérable diversitè, est le révélateur, la révélation et le révélé». Cf. Juan Alfaro. “Cristo glorioso, Revelador del Padre”. Gregorianum 39 (1958): 222-270. Íd. "Las funciones salvíficas de Cristo como Revelador, Señor y Sacerdote". En Mysterium Salutis. Vol.III/I, dirigido por Johannes Feiner y Magnus Löhrer, 671755. Madrid: Cristiandad, 1971. 
es el reflejo de ese amor y misericordia que nos desvela el rostro mismo del Padre para que todos los hombres obtengamos la plenitud de la vida por medio de Él (cf. DV 4).

La revelación resulta marcada cristológicamente en un sentido objetivo y subjetivo. Cristo es objeto y sujeto de la revelación. Él es el revelador y a la vez el contenido fundamental de la revelación divina. Por este motivo es claro que la revelación en Cristo tiene un valor teológico y antropológico, en cuanto que Cristo revela el misterio de Dios y su proyecto para el hombre, tal y como aparece también en el texto de Aparecida del que J. M. Bergoglio fue el presidente de la comisión redactora ${ }^{46}$.

Por otro lado, se evidencia en el pensamiento de Francisco la profundidad doctrinal y la perspectiva teológica que aparece en la Constitución Dei Verbum del Vaticano II:

«Jesucristo — ver al cual es ver al Padre-, con su total presencia y manifestación personal, con palabras y obras, señales y milagros, y, sobre todo, con su muerte y resurrección gloriosa de entre los muertos; finalmente, con el envío del Espíritu de verdad, completa la revelación y confirma con el testimonio divino que vive en Dios con nosotros para librarnos de las tinieblas del pecado y de la muerte y resucitarnos a la vida eterna ${ }^{47}$.

Francisco ha insistido desde los inicios de su pontificado en que Jesús es quien con su palabra, con sus gestos y con toda su persona revela la misericordia de Dios (cf. MV 1). Pues «Él es el rostro de la misericordia» (MV 8), cuya manifestación plena ha tenido lugar en la cruz, en el misterio de su muerte y resurrección (cf. EG 285). En el vértice de la revelación del misterio de Dios se halla el misterio pascual que representa la victoria definitiva de la misericordia sobre la miseria humana (cf. EG 278).

${ }^{46}$ Cf. Consejo Episcopal Latinoamericano. Documento conclusivo de la V Conferencia General del Episcopado Latinoamericano y del Caribe (Aparecida, 13-31 de mayo de 2007): "Discípulos y misioneros de Jesucristo para que nuestros pueblos en Él tengan vida» (Jn 14,6). Bogotá: Centro de publicaciones del CELAM-Paulinas, 2008, n. 6. Cf. Jorge Mario Bergoglio - Papa Francesco, 127. Cf. Casula, 18-19.

47 DV 4. Las referencias en DV a Cristo son abundantes. En opinión de A. Blanco la categoría Cristo plenitud de la revelación es un concepto expresamente enseñado por el Vaticano II y responde a una "deliberada intención del Concilio». Arturo Blanco. “La cristología en la Constitución 'Dei Verbum”". En Cristo, Hijo de Dios y Redentor del hombre, dirigido por Lucas F. Mateo-Seco, 329-330. Pamplona: Universidad de Navarra, 1982. 
Es la belleza del amor salvífico de Dios que se ha manifestado en Cristo muerto y resucitado (cf. EG 36) y en su presencia misericordiosa en medio de los hombres.

El papa ha querido subrayar la centralidad que tiene en el camino de la santidad la persona de Cristo por cuanto nos desvela el rostro de Dios saliendo a nuestro encuentro, y llevando como mediador la misma revelación a su culmen y plenitud (cf. DV 2 y 4). En efecto, «toda la vida de Cristo es revelación del Padre» (GE 20).

\subsection{CRISTO ES MISTERIO DE REDENCIÓN}

La redención de Jesús es el tercer tema que aparece enumerado en GE y se desarrolla en varios momentos del documento. En especial cuando se refiere al tema de la cruz y a la implicación de cada creyente con la carne sufriente del hermano pobre. En palabras de Francisco:

«La santidad que Dios regala a su Iglesia viene a través de la humillación de su Hijo, ése es el camino. La humillación te lleva a asemejarte a Jesús, es parte ineludible de la imitación de Jesucristo: "Cristo padeció por vosotros, dejándoos un ejemplo para que sigáis sus huellas" (1P 2,21). Él a su vez expresa la humildad del Padre, que se humilla para caminar con su pueblo, que soporta sus infidelidades y murmuraciones (cf. Ex 34,6-9; Sb 11,23-12,2; Lc 6,36)» ${ }^{48}$.

La redención llega a nosotros a través de la humillación de Cristo muerto y resucitado que recompone nuestra humanidad fragmentada por las fatigas de la vida y por el pecado (cf. GE 151). «No hay que domesticar el poder del rostro de Cristo» (GE 151), pues él es siempre más y aunque se viva en la sinrazón siempre nos sorprende. La santificación es un proceso, un camino de búsqueda del rostro de Jesús para experimentar su amor y redención. "Y si ante el rostro de Cristo todavía no logras dejarte sanar y transformar, entonces penetra en las entrañas del Señor, entra en sus llagas, porque allí tiene su sede la misericordia divina» (GE 151) ${ }^{49}$.

Esta redención se actualiza y llega a nosotros a través de la lectura orante de la palabra de Dios (cf. GE 156) y de la eucaristía (cf. GE 157).

\footnotetext{
48 GE 118. Cf. supra 4.2.

49 Francisco sigue aquí la tradición espiritual de S. Bernardo. Sermones sobre el Cantar de los Cantares, 61, 3-5: PL 183: 1071-1073.
} 
La primera hace posible la escucha del Maestro. Es lámpara para nuestros pasos y luz en nuestro camino. Ella tiene en sí el poder para transformar nuestras vidas (cf. GE 156). La eucaristía, por otro lado, es presencia real de Cristo que se ofrece para el perdón de los pecados. Cuando lo recibimos en la comunión se renueva nuestra alianza con él y le permitimos que realice en nosotros más y más su obra trasformadora y redentora (cf. GE 157).

Como dijimos más arriba, dicha redención implica también una lucha contra las fuerzas del mal que se expresa en el combate espiritual y personal que cada creyente está llamado a superar (cf. GE 163-165). Además de poner los medios adecuados, es necesario ejercitarse en el discernimiento como instrumento que ayuda al discípulo misionero a crecer en el camino de la maduración espiritual y humana (cf. GE 166-168). «Es un instrumento de lucha para seguir mejor al Señor» (GE 169) en un continuo camino de crecimiento, puesto que «él nos llama a examinar lo que hay dentro de nosotros - deseos, angustias, temores, búsquedas- y lo que sucede fuera de nosotros - "los signos de los tiempos"- para reconocer los caminos de la libertad plena» (GE 168) $)^{50}$.

Por último, para experimentar la redención en nosotros es necesario descubrir la eterna novedad de Cristo, pues siempre nos conduce allí donde se encuentra la humanidad más herida, sufriente, y donde los hombres siguen buscando la respuesta a la gran pregunta por el sentido de la vida. Porque Cristo va siempre más allá de nuestros esquemas, nos pone en movimiento (cf. GE 135). De este modo, insiste Francisco, en que si nos arriesgamos a llegar hasta las periferias lo encontraremos porque «Jesús nos primerea en el corazón de aquel hermano, en su carne

${ }^{50}$ En la exhortación postsinodal Christus Vivit el papa ha vuelto a insistir en el tema del discernimiento dedicándole el capítulo último. Cf. Christus Vivit, nn. 278298. También cf. Evangelii gaudium, n. 50; Amoris laetitia, nn. 291-312. Cf. A. Barruffo. "Discernimiento". En Nuevo Diccionario de Espiritualidad, dirigido por Stefano de Fiores, Tullo Goffi, y Augusto Guerra, 484-495. 5. ${ }^{a}$ ed. Madrid: Paulinas, 1991. Para el tema del discernimiento en los Ejercicios espirituales, cf. Santiago Arzubialde. Ejercicios Espirituales de S. Ignacio. Historia y análisis. 2. ${ }^{a}$ ed. Santander: Mensajero, 2009, 797-798; 851-860. Para una comprensión de GE como propuesta ignaciana de santidad apostólica, cf. G. Uríbarri. Santidad misionera, 131-166, esp. 153-158; para el Magis ignaciano en GE, cf. Uríbarri, 163-164; 181. Más ampliamente, cf. Nuria Martínez-Gayol y Luis de Diego. "Magis". En Diccionario de Espiritualidad Ignaciana. Vol. II, dirigido por Grupo de Espiritualidad Ignaciana, 1155-1168. Santander: Mensajero, 2007. 
herida, en su vida oprimida, en su alma oscurecida. Él ya está allí» (GE 135), y nos espera.

El valor redentor del misterio de Cristo es el tercer elemento cristológico que se pone de relieve en GE. No podía ser de otra manera: Cristo ha venido a redimir, a buscar y a salvar lo que estaba perdido. La santidad nos invita a vivir este misterio redentor porque «toda la vida de Cristo es misterio de redención» (GE 20).

\subsection{CRISTO ES Misterio DE RECAPITULACIÓN}

La vida de Cristo abarca también el misterio de la recapitulación. Porque todo lo que Cristo hizo, enseñó y padeció fue para restablecer al hombre caído en su vocación primera, y mostrar el camino de la santidad a la que todo hombre está llamado ${ }^{51}$. La vocación última del hombre es la vocación divina (cf. GS 22).

Por medio de su encarnación, el Hijo de Dios lleva a cabo la recapitulación de la historia humana y enaltece aquella vocación primitiva que el hombre perdió a causa del pecado de los orígenes. San Ireneo había afirmado que Cristo «cuando se encarnó y se hizo hombre, recapituló en sí mismo la larga historia de la humanidad procurándonos en su propia historia la salvación de todos, de suerte que lo que perdimos en Adán, es decir, el ser imagen y semejanza de Dios, lo recuperamos en Cristo Jesús». Por este motivo es por el que Cristo ha vivido «todas las edades de la vida humana, devolviendo así a todos los hombres la comunión con Dios ${ }^{52}$. Consecuentemente, fruto de esta comunión entre Cristo y el hombre, escribe Francisco que «el designio del Padre es Cristo, y nosotros en él. En último término, es Cristo amando en nosotros» (GE 21). Si el designio del Padre es Cristo y Cristo en nosotros, se puede concluir que la santidad consiste en vivir esta inhabitación cristológica en la existencia del creyente.

Dios, por otro lado, ha querido salvarnos a través de su Hijo. El misterio de la recapitulación llega hasta nosotros reclamando la posibilidad de ser imagen testimonial del amor de Cristo para con los demás. Todo fue creado por él y para él, en él todo subsiste (cf. Col 1,16-17). El designio amoroso del Padre entra en el tiempo y en la historia humana a través

51 Cf. Castro Pérez, 135-150.

${ }^{52}$ Ireneo de Lyon. Adversus haereses. III, 18,1; III, 18,7. Cf. II, 22,4. 
del Hijo de Dios encarnado. Él es el principio y el fin, el alfa y la omega (cf. GS 40). La recapitulación de todas las cosas en Cristo Jesús abarca al menos tres elementos fundamentales: el universo creado, la historia humana y el individuo concreto. Creación, historia e individuo son objeto de la recapitulación cristológica que se consumará al final de los tiempos cuando Cristo sea todo en todo (1Cor 15,28). La santidad implica descubrir la dimensión escatológica de la vida cristiana. Se trata de una existencia habitada por Cristo que camina en el tiempo presente, que en esta hora ya sí nos ha sido dada como gracia, pero todavía no consumada en plenitud hasta que el mismo Cristo vuelva al final de los tiempos. Mientras tanto la Iglesia camina en la historia con la certeza de que «toda la vida de Cristo es misterio de recapitulación» (GE 20).

\subsection{MÁs Y MÁs CON CRISTO}

Francisco afirma que «todo lo que Cristo vivió hace que podamos vivirlo en él y que él lo viva en nosotros» (GE 20). La cristología que aparece en GE tiene como objetivo la configuración de cada cristiano con el misterio de Cristo. La dimensión cristológica está intrínsecamente unida a la universal llamada a la santidad que el papa recuerda en este texto. La santidad "es la caridad plenamente vivida» como recordaba el papa Benedicto XVI. Y se mide "por la estatura que Cristo alcanza en nosotros, por el grado como, con la fuerza del Espíritu Santo, modelamos toda nuestra vida según la suya $»^{53}$. Así la santidad es el dinamismo que nos lleva a vivir la propia entrega de tal manera que nuestros esfuerzos tengan un sentido evangélico "y nos identifiquen cada día más y más con Cristo» (GE 28).

Varios elementos caben destacar: a) el hombre se transforma y avanza en el camino de la santidad a través de la configuración de su existencia con Cristo; b) la inhabitación de Cristo reclama del creyente la apertura y docilidad para que él mismo pueda ser amado en nosotros y a través nuestro; y, c) la modelación de nuestra vida a la de Cristo se realiza a través del Espíritu Santo, superando cualquier tipo de cristocentrismo

${ }^{53}$ GE 21, donde cita a Benedicto XVI. Catequesis (13 abril 2011). En L'Osservatore Romano. ed. semanal en lengua española (17 abril 2011): 11. 
cerrado, para dar paso a la cristología pneumática de la que hemos hablado anteriormente ${ }^{54}$.

Siendo la vida del cristiano una misión y sabiendo que cada uno tiene una misión que Dios le confía, la santidad no es posible sin el encuentro personal y profundo con Cristo. El santo es aquel que se ha dejado encontrar por Cristo, que se identifica con él cada vez más y más, que vive sus mismos sentimientos y se configura con sus mismas actitudes. Relee su vida a la luz de Cristo vivo y resucitado, descubriendo su presencia y su llamada en la propia historia personal. Supone dejarse encontrar por Cristo. El santo refleja algo de él, de la riqueza de su persona y la muestra a los demás.

A cada creyente se le pide una apertura radical para que se forje en él "ese misterio personal que refleje a Jesucristo en el mundo de hoy» (GE 23). El santo es otro «cristo» en la historia, en medio del mundo en el que vive.

Solo la identificación con Cristo y con sus deseos más profundos hace posible que cada uno pueda construir, con él y junto a él, el reino del amor, justicia y paz en nuestros días. Es Cristo mismo el que quiere vivir con cada uno esa entrega generosa, cargada de esfuerzo o renuncia, de alegría y esperanza para que podamos ofrecer lo mejor de nosotros mismos (cf. GE 23-25).

El encuentro con Cristo conduce a la contemplación de la historia para que lejos de encerrarnos en nosotros mismos podamos seguir adelante, respondiendo a los retos y abiertos a la novedad que el Señor nos proponga (cf. GE 139; 153). De esta forma, la historia se convierte en un lugar teológico en la que acontece el misterio de la encarnación del Hijo de Dios y en su carne se cumple el misterio de su muerte y resurrección. La historia es, además, ese lugar donde el misterio de Cristo continúa manifestándose y cumpliéndose en el pueblo de Dios y en la existencia de cada cristiano. Ella es el lugar fundamental para la cristología porque es aquí donde se produce el conocimiento de Cristo a través del encuentro personal con él y de las relaciones con Dios, con el prójimo y con todo lo creado ${ }^{55}$. Por esta razón «todo lo que Cristo vivió hace que podamos vivirlo en él y que él lo viva en nosotros» (GE 20).

\footnotetext{
54 Cf. Supra 4.

55 Cf. Casulla, 111-115.
} 


\section{CONCLUSIÓN: LA PERSONA DE CRISTO, FUENTE DE VIDA PARA ALCANZAR LA SANTIDAD}

Se ha expuesto a lo largo de estas páginas los aspectos cristológicos más destacados de la exhortación apostólica GE. No se pretende abarcarlos todos, ni agotar el rico contenido del documento. Trazando las grandes líneas propositivas que Francisco enseña, se han subrayado los elementos más relevantes que merecen nuestra consideración para poner de relieve la dimensión cristológica de la exhortación. No hay santidad sin Cristo y no habrá una auténtica misión evangelizadora sin una Iglesia santa. A modo de síntesis, se enumeran finalmente las siguientes conclusiones:

1. El papa Francisco ha insistido por medio de GE en la importancia de la llamada a la santidad para toda la Iglesia proponiéndola como elemento de credibilidad y testimonio para el anuncio del Evangelio en nuestros días. Algo nos debe quedar claro: cada santo es una misión (cf. GE 19) y sin santidad no hay misión evangelizadora de la Iglesia. Se puede afirmar, por tanto, que GE despliega la conversión personal y pastoral necesaria para la reforma de la Iglesia que tanto reclama el magisterio pastoral de Francisco.

Esta llamada hunde sus raíces en el capítulo V de la LG donde el Vaticano II propone la común universal llamada a la santidad de todo el pueblo de Dios. En este sentido GE supone una nueva recepción conciliar de una cuestión de vital relevancia para el contexto evangelizador en el que cada bautizado debe ejercer su misión.

2. GE es un texto rico en su contenido y de fácil lectura. Con un estilo propio, Francisco presenta la santidad al alcance de toda la Iglesia y como una posibilidad real en la vida del discípulo misionero. La propone a todos como un elemento configurador del programa pastoral que nos había dado en Evangelii gaudium. Si en la primera exhortación se insiste en el anuncio misionero, esto es, en lo que la Iglesia debe hacer, ahora en GE se presenta el modo, el cómo se tiene que hacer ese anuncio: siendo santos. La santidad es posible para todo el pueblo de Dios. Se puede vivir en lo cotidiano de cada día, en lo ordinario y particular de cuanto somos y hacemos. La santidad no es para «superhombres». Tiene su centro y fundamento en el encuentro con Cristo y, 
de manera particular, en la vivencia de las bienaventuranzas y la propuesta fraterna de Mt 25.

3. Para reflexionar sobre la santidad se hace necesario ahondar en el contenido cristológico y en la perspectiva cristocéntrica que el documento contiene, y que se han presentado a lo largo de estas líneas. El misterio de Cristo, el encuentro con Él, la centralidad de Cristo en la vida de la Iglesia y en cada creyente, harán posible que la santidad sea vivida y testimoniada como una santidad para la misión o una santidad apostólica. Esta santidad supera las tentaciones y obstáculos propios de nuestra condición humana y se fortalece con los medios necesarios para combatir la acedia y la mundanidad espiritual.

4. Sin Cristo no hay santidad. Sin Cristo no hay espiritualidad cristiana. GE es expresión de una espiritualidad de la santidad necesaria en nuestros días. Así el papa enriquece los diversos modelos de espiritualidad que a lo largo de su magisterio pastoral está proponiendo a la Iglesia.

En Evangelii gaudium Francisco nos ha hablado de una espiritualidad para la misión marcada por la alegría. En Laudato si', nos ha presentado una espiritualidad ecológica, en Amoris laetitia ha subrayado de manera insistente la alegría de vivir una espiritualidad familiar (cf. GE 28). Por último, en Gaudete et exsultate nos propone una verdadera espiritualidad de la santidad con el fin de hacer frente al desafío de vivir la propia existencia diaria, y a que la Iglesia viva con un sentido cada vez más evangélico para identificarse más y más con Cristo (cf. GE 28).

5. Por último, proponemos una lectura de GE en clave cristológica y cristocéntrica en coherencia con el modo que tiene Francisco de entender la santidad. Una lectura cristológica que nos ayude a centrar la atención en lo esencial del documento, esto es, en Cristo que nos llama a la santidad. O en una llamada a la santidad cuyo fundamento, centro y fin tiene su inspiración en el mismo Cristo. Así, la persona de Jesucristo se convierte en la fuente de vida espiritual indispensable para alcanzar la santidad. El imperativo de GE para todo el pueblo de Dios no es otro que el de configurar la existencia con Cristo. Nos parece que en GE la razón teológica última que puede explicar la santidad misionera es la persona de Cristo, su imitación —imitatio Christi- (cf. GE 120) y su seguimiento radical. Porque, en definitiva, la santidad es vivir una felicidad plena que el mundo no nos podrá quitar. 


\section{REFERENCIAS}

Alfaro, Juan. "Cristo glorioso, Revelador del Padre". Gregorianum 39 (1958): 222-270.

Alfaro, Juan. "Las funciones salvíficas de Cristo como Revelador, Señor y Sacerdote". En Mysterium Salutis. Vol. III/I, dirigido por Johanes Feiner y Magnus Löhrer, 671-755. Madrid: Cristiandad, 1971.

Alfaro, Juan. Revelación cristiana, fe y teología. Salamanca: Sígueme, 1974. Aparicio Valls, María del Carmen. "La Palabra significativa". En Del clavo a la clave. La teología fundamental del papa Francisco, dirigido por Michelina Tenace, 19-28. Madrid: BAC, 2018.

Arzubialde, Santiago. Ejercicios Espirituales de S. Ignacio. Historia y análisis. 2. ${ }^{a}$ ed. Santander: Sal Terrae, 2009.

Balthasar, Hans Urs von. "Teología y santidad”. En Verbum Caro, 235-268. Madrid: Cristiandad, 1964.

Barruffo, A. "Discernimiento". En Nuevo Diccionario de Espiritualidad, dirigido por Stefano de Fiores, Tullo Goffi, y Augusto Guerra, 484-495. 5. ${ }^{a}$ ed. Madrid: Paulinas, 1991.

Barth, Karl. Dogmatique. La doctrine de la parole de Dieu. Vol. I. Genéve: Labor et Fide, 1953.

Benedetti, Jorge, y Carlos María Galli. Francisco: la alegría que brota del pueblo. Una reflexión compartida de Evangelii gaudium. Buenos Aires: Santa María, 2015.

Bergoglio, Jorge Mario - Papa Francesco. Aprite la mente al vostro cuore. Milano: Rizzoli, 2014.

Blanco, Arturo. “La cristología en la Constitución ‘Dei Verbum”'. En Cristo, Hijo de Dios y Redentor del hombre, dirigido por Lucas F. Mateo-Seco, 325-340. Pamplona: Universidad de Navarra, 1982.

Boff, Leornado. Jesucristo y la liberación del hombre. Madrid: Cristiandad, 1981.

Bueno, Eloy. Los rostros de Cristo en la teología contemporánea. Madrid: BAC, 1997.

Castro Pérez, Francisco A. Luz de los hombres. Fundamentos de antropología pastoral. Santander: Sal Terrae, 2019.

Casula, Lucio. Volti, gesti e luoghi. La cristologia di papa Francesco. Città del Vaticano: Editrice Vaticana, 2017. 
Checa, Rafael. "Pastoral de espiritualidad". En Nuevo Diccionario de Espiritualidad, dirigido por Stefano de Fiores, Tullo Goffi, y Augusto Guerra, 1484-1500. 5. ${ }^{a}$ ed. Madrid: Paulinas, 1991.

Chenu, Marie Dominique. Église et pauvreté. Paris: Du Cerf, 1965.

Chenu, Marie Dominique. "La Iglesia de los pobres' en el Vaticano II". Concilium 13, n. ${ }^{\circ}$ (1972): 73-79.

Congar, Yves Marie. Pour une Église servante et pauvre. Paris: Du Cerf, 1963.

Congregación para la Doctrina de la fe. Placuit Deo. Carta a los Obispos de la Iglesia Católica sobre algunos aspectos de la salvación cristiana, (22 de febrero de 2018). AAS 110 (2018): 427-436.

Consejo Episcopal Latinoamericano. Documento conclusivo de la V Conferencia General del Episcopado Latinoamericano y del Caribe (Aparecida, 13-31 de mayo de 2007): "Discípulos y misioneros de Jesucristo para que nuestros pueblos en Él tengan vida" (Jn 14,6). Bogotá: Centro de publicaciones del CELAM-Paulinas, 2008.

Cordovilla, Ángel. "La carta Placuit Deo sobre la salvación cristiana. Contenido y recepción”. Almeriensis 11 (2018): 333-342.

Corintios XIII. Evangelii gaudium. Los pobres en el corazón de la misión de la Iglesia, 149 (2014).

Francisco. Carta encíclica Lumen fidei (29 de junio de 2013). AAS 105 (2013): 555-596.

Francisco. Exhortación apostólica Evangelii gaudium (24 de noviembre de 2013). AAS 105 (2013): 1020-1137.

Francisco. Exhortación apostólica Amoris Laetitia (19 de marzo de 2016). AAS 108 (2016): 311-446.

Francisco. Videomensaje al Congreso Internacional de Teología organizado por la Pontificia Universidad Católica Argentina (1-3 de septiembre de 2015). AAS 107 (2015): 977-982.

Francisco. Discurso a los participantes en el $V$ Congreso de la Iglesia Italiana (10 de noviembre de 2015). AAS 107 (2015): 1268-1271.

Francisco. Discurso a la Comunidad académica del Pontificio Instituto "Juan Pablo II" (27 de octubre de 2016). AAS 108 (2016): 1226-1230.

Francisco. Constitución apostólica Veritatis gaudium (8 de diciembre de 2017). AAS 110 (2018): 1-34.

Francisco. Exhortación apostólica Gaudete et exsultate. Sobre el llamado a la santidad en el mundo actual. (19 de marzo de 2018). http:// www.vatican.va/content/francesco/es/apost_exhortations/documents/ 
papa-francesco_esortazione-ap_20180319_gaudete-et-exsultate.html. Consultado el 14 de enero de 2020.

Francisco. Exhortación apostólica postsinodal Christus Vivit (25 de marzo 2019). http://www.vatican.va/content/francesco/es/apost_exhortations/ documents/papa-francesco_esortazione-ap_20190325_christus-vivit. html. Consultado el 26 de enero de 2020.

Galli, Carlos María. Dios vive en la ciudad. Hacia una nueva etapa pastoral urbana a la luz de Aparecida y del proyecto misionero de Francisco. 3. ${ }^{\mathrm{a}}$ ed. Barcelona: Herder, 2014.

Galli, Carlos María. "La giogia e la tenerezza del Vangelo. 'Il Codice Francesco"”. Vita Pastorale 3 (2014): 62-65.

Galli, Carlos María. "La teología pastoral de Evangelii gaudium en el proyecto misionero de Francisco". Revista Teología 114 (2014): 29-59.

Galli, Carlos María. "La teología pastoral de Aparecida, una de las raíces latinoamericanas de Evangelii gaudium". Gregorianum 96 (2015): 25-50.

Gil Canto, Salvador. La Cristología del Vaticano II. Una relectura a los cincuenta años. Salamanca: Secretariado Trinitario, 2015.

Gil Canto. Cristo renueva su Iglesia. Una reflexión a la luz del Vaticano II y la Evangelii gaudium. Málaga: Anarol, 2017.

González Faus, José Ignacio. La humanidad nueva. Ensayo de cristología. 8. ${ }^{\text {a }}$ ed. Santander: Sal Terrae, 1984.

Granados, José. Teología de los misterios de la vida de Jesús. Salamanca: Sígueme, 2009.

Guerra, Augusto. “Teología espiritual”. En Nuevo Diccionario de Espiritualidad, dirigido por Stefano de Fiores, Tullo Goffi, y Augusto Guerra, 1841-1845. 5. ${ }^{\mathrm{a}}$ ed. Madrid: Paulinas, 1991.

Gutiérrez, Gustavo. En busca de los pobres de Jesucristo. Salamanca: Sígueme, 1993.

Iparraguirre, Ignacio. "Naturaleza de la santidad y medios para conseguirla”. En La Iglesia del Vaticano II. Vol. II, dirigido por Guillermo Baraúna, 1073-1088. Barcelona: Juan Flors, 1966.

Juan Pablo II. Carta apostólica Novo millennio ineunte (6 enero 2001). AAS 93 (2001): 266-309.

Juan XXIII. Discurso en la solemne apertura del Concilio Vaticano II Gaudet Mater Ecclesia (11 de octubre de 1962). AAS 54 (1962): 786-796.

Kasper, Walter. La misericordia. Clave del Evangelio y de la vida cristiana. 7. ${ }^{a}$ ed. Santander: Sal Terrae, 2015. 
Labourdette, M. "La santidad, vocación de todos los miembros de la Iglesia". En La Iglesia del Vaticano II. Vol. II, dirigido por Guillermo Baraúna, 1061-1071. Barcelona: Juan Flors, 1966.

Latourelle, René. Cristo y la Iglesia signos de salvación. Salamanca: Sígueme, 1971.

Latourelle, René. Teología de la revelación. 11. . ed. Salamanca: Sígueme, 2005.

Lois, Julio. Jesús de Nazaret, el Cristo libertador. Madrid: Hoac, 1995.

López Peñalba, Jaime. "La vocación universal a la santidad en Gaudete et exsultate". Teología y catequesis 144 (2019): 31-56.

Loyola, Ignacio de. Ejercicios espirituales. Santander: Sal Terrae, 2019.

Madrigal, Santiago. "La 'Iglesia en salida': la misión como tema eclesiológico”. Revista Catalana de Teología 40, n. 2 (2015): 425-458.

Martínez-Gayol, Nuria, y Luis de Diego. "Magis". En Diccionario de Espiritualidad Ignaciana. Vol. II, dirigido por Grupo de Espiritualidad Ignaciana, 1155-1168. Santander: Mensajero, 2007.

Mazzolini, Sandra. "Vocazione universale alla santità nella Chiesa". En Commentario ai documenti del Vaticano II, Lumen Gentium 2, dirigido por Serena Noceti y Roberto Repole, 355-375. Bologna: Dehoniane, 2015.

Müller, Phillipp. "Miserando atque eligendo". En El evangelio de la misericordia, dirigido por George Augustin, 85-98. Santander: Sal Terrae, 2016.

O'Callaghan, Paul. "Il significato ermeutico della chiamata universale alla santitá". PATH 18, n. 1 (2019): 23-41.

Philips, Gérard. La Iglesia y su misterio en el Concilio Vaticano II. Historia, texto y comentario de la Constitución "Lumen Gentium". Vol. II. Barcelona: Herder, 1969.

Planellas i Barnosell, Joan. La Iglesia de los pobres en el Concilio Vaticano II. Barcelona: Herder, 2014.

Pontificio Consejo para la Promoción de la Nueva Evangelización. Misericordiosos como el Padre. Subsidio para el Jubileo de la Misericordia 2015-2016. Madrid: BAC, 2015.

Rahner, Karl. "Problemas actuales de cristología”. En Escritos de Teología. Vol. I. 167-221. Madrid: Taurus, 1961.

Rahner, Karl. "Eterna significación de la humanidad de Jesús para nuestra relación con Dios". En Escritos de Teología. Vol. III. 47-59. Madrid: Taurus, 1962. 
Rahner, Karl. "Para la teología de la Encarnación”. En Escritos de Teología. Vol. IV. 131-148. 4. " ed. Madrid: Cristiandad, 2002.

Rakotobe, Dominique. "Los santos de la puerta de al lado". Revista de espiritualidad 308 (2018): 427-493.

Rocco, Ugo. "Universale vocazione alla santità nella Chiesa". En La Costituzione dogmatica sulla Chiesa, 731-756. Torino: Elle Di Ci, 1965.

Sartori, Luigi. La "Lumen Gentium". Traccia di studio. 2. ${ }^{\text {a }}$ ed. Padova: Messaggero, 2003.

Sartorio, Ugo. Santità per tutti. Una lettura dell'esortazione apostolica Gaudete et exsultate. Milano: Ancora, 2019.

Sobrino, Jon. Jesucristo liberador. Madrid: Trotta, 1991.

Sobrino, Jon. La fe en Jesucristo. Ensayo desde las víctimas. Madrid: Trotta, 1999.

Spadaro, Antonio. "Radici, struttura e significato della prima Esortazione apostolica di papa Francesco". La Civiltá Cattolica 3923 (2013): 417-433.

Spadaro, Antonio. "Gaudete et exsultate. Radici, struttura e significato della Esortazione apostolica di papa Francesco". La Civiltà Cattolica 4028, n. ${ }^{\circ} 2$ (2018): 107-123.

Uríbarri, Gabino. La singular humanidad de Jesucristo. Madrid: San Pablo, 2008.

Uríbarri, Gabino. La mística de Jesús. Desafío y propuesta. Santander: Sal Terrae, 2017.

Uríbarri, Gabino. Teología de ojos abiertos: Doctrina, cultura y evangelización. Santander: Sal Terrae, 2018.

Uríbarri, Gabino. Santidad misionera. Fuentes, marco y contenido de Gaudete et exsultate. Santander: Sal Terrae, 2019.

Uríbarri, Gabino. "Placuit Deo: tres claves de lectura. La carne de Cristo frente a dos dioses de nuestra cultura". Ecclesia 78, n. 3933 (2019): 24-25.

Uríbarri, Gabino. "La santidad de los discípulos misioneros. La recepción del Concilio Vaticano II en Gaudete et exsultate". CONFER 58, n. ${ }^{\circ} 221$ (2019): 31-53.

Villafiorita, Andrea. "Un nuovo ordine di relazioni in Cristo: note in margine alla 'Placuit Deo”'. Rassegna di Teologia 59 (2018): 181-196. 